\title{
POPULATION STRUCTURE AND MITOCHONDRIAL POLYPHYLY IN NORTH AMERICAN GADWALLS (ANAS STREPERA)
}

\author{
Jeffrey L. Peters ${ }^{1}$ and Kevin E. Omland \\ Department of Biological Sciences, University of Maryland Baltimore County, 1000 Hilltop Circle, Baltimore, \\ Maryland 21250, USA
}

\begin{abstract}
Aвstract. - We examined population genetic structure in Gadwalls (Anas strepera) to test the prediction that female philopatry and fidelity to migratory flyways have contributed to the partitioning of mitochondrial variation across North America. Sequencing a 658-659 base-pair fragment of the mitochondrial DNA (mtDNA) control region from 348 Gadwalls, we found two distinct clades that were broadly intermixed across both breeding and nonbreeding populations. Clade A was abundant in North America as well as among published sequences from Eurasia. Clade B was sequenced from 5.5\% of North American Gadwalls and was more similar to Asian Falcated Duck (A. falcata) haplotypes than to clade A haplotypes. Maximum likelihood indicated that Gadwall clade B haplotypes were a monophyletic group nested within Falcated Duck haplotypes, which suggests mtDNA introgression of clade B into Gadwalls. However, that topology was weakly supported, and we could not reject topologies that were consistent with incomplete lineage-sorting as the cause of mitochondrial polyphyly. Migratory flyways did not contribute significantly to population structure and, in general, we found a lack of genetic structure among most populations. However, Gadwalls sampled in Alaska and Washington were well differentiated from other populations. Coalescent analyses supported a historical population expansion for clade $\mathrm{A}$, and this expansion could have contributed to the high genetic similarity among some populations but the strong differentiation of others. Female-mediated gene flow, along with both historical and contemporary population and range expansions, has likely contributed to the overall weak mtDNA structure in North American Gadwalls. Received 27 October 2005, accepted 25 March 2006.
\end{abstract}

Key words: Anas falcata, Anas strepera, Anatidae, Falcated Duck, Gadwall, mitochondrial DNA, phylogeography, polyphyly, population expansion.

\section{Estructura Poblacional y Polifilia Mitocondrial en Anas strepera}

Resumen. - Examinamos la estructura genética poblacional en Anas strepera para poner a prueba la predicción de que la filopatría de las hembras y la fidelidad a los corredores de vuelo han contribuido a la partición de la variación mitocondrial a través de Norte América. Secuenciamos un fragmento de la región control del ADN mitocondrial (ADNmt) de 658-659 pares de bases para 348 individuos, y encontramos dos clados distintos que se encontraron ampliamente distribuidos a través de poblaciones reproductivas y no reproductivas. El clado A fue abundante en Norte América, y también en secuencias publicadas de Eurasia. En el clado B se ubicaron el 5.5\% de los individuos de Norte América, y fue más similar a haplotipos de A. falcata que a los haplotipos del clado A. De acuerdo a análisis de

\footnotetext{
${ }^{1}$ Present address: Institute of Arctic Biology, University of Alaska Fairbanks, Fairbanks, Alaska 99775, USA.

E-mail: jpeters@iab.alaska.edu
} 
máxima verosimilitud, los haplotipos de $A$. strepera presentes en el clado B forman un grupo monofilético que se encuentra anidado dentro del clado de haplotipos de $A$. falcata, lo que sugiere que ha existido introgresión mitocondrial del clado $B$ hacia $A$. strepera. Sin embargo, esa topología no está bien respaldada, y no pudimos rechazar topologías consistentes con la hipótesis de que la polifilia mitocondrial sería el resultado de un proceso de separación incompleta de linajes. Los corredores de vuelos migratorios no contribuyeron significativamente a la estructura poblacional y, en general, no encontramos estructura genética entre la mayoría de las poblaciones. Sin embargo, los individuos de A. strepera muestreados en Alaska y Washington estuvieron bien diferenciados de los de otras poblaciones. Análisis de coalescencia apoyaron una hipótesis de expansión poblacional, y esta expansión podría haber contribuido a la alta similitud genética entre algunas poblaciones y la marcada diferenciación de otras. El flujo genético mediado por las hembras, junto con expansiones poblacionales históricas y contemporáneas, probablemente han contribuido a la estructura débil del ADNmt entre las poblaciones norteamericanas de A. strepera.

Phylogeographic surveys of mitochondrial DNA (mtDNA) have revealed diverse patterns of genetic variation among species (reviewed in Avise 2000). This variation is partitioned among populations as a result of complex interactions between contemporary and historical gene flow as well as other demographic processes. Many species are strongly structured across their ranges, and different geographic regions sometimes harbor distinct mtDNA lineages, which suggests that gene flow has been historically restricted (e.g., Milot et al. 2000, Omland et al. 2000, Drovetski et al. 2004). Other species seem to be genetically homogeneous across their ranges, which suggests regular gene flow. However, range expansions can also result in high genetic similarity among populations. For some species, expansions from multiple source populations seem to have contributed to broad intermixing of distinct mtDNA lineages across a species' range (e.g., Avise et al. 1992, Quinn 1992, Lambert et al. 2002, Ruokonen et al. 2004).

Multiple mtDNA lineages sometimes render a species' mtDNA paraphyletic or polyphyletic with respect to mtDNA of other closely related species; that is, some haplotypes are more closely related to haplotypes of other species than to haplotypes of some conspecifics. In a survey of published phylogenetic and phylogeographic studies, Funk and Omland (2003) observed that $17 \%$ of bird species had nonmonophyletic mtDNA. Within ducks in the genus Anas, several species have paraphyletic or polyphyletic mtDNA, and both incomplete lineage sorting and interspecific hybridization likely contributed to these patterns (Avise et al. 1990; Rhymer et al. 1994; Omland 1997; Johnson and Sorenson 1999; McCracken et al. 2001; Kulikova et al. 2004, 2005; Peters et al. 2005b). Ducks are well known for their ability to hybridize and produce fertile offspring, and some species regularly hybridize in sympatry (Johnsgard 1960, Tubaro and Lijtmaer 2002, Mallet 2005). In addition, the genus Anas underwent a rapid radiation (Johnson and Sorenson 1999), and some species likely diverged too recently for mtDNA to have sorted to monophyly (Avise et al. 1990, Omland 1997). Determining the reasons why different species share mtDNA lineages can be difficult in this group, and in other recently radiated groups, because species that are likely to have incompletely sorted mtDNA are also likely to hybridize (e.g., McCracken et al. 2001, Tubaro and Lijtmaer 2002, Kulikova et al. 2004).

The Gadwall (Anas strepera) has a Holarctic distribution extending across Europe, Asia, and North America. This range crosses a number of potential barriers to dispersal, including oceans, mountain ranges, deserts, and other uninhabited areas. Although the Gadwall is migratory and can likely traverse large expanses of inhospitable environments, several behavioral characteristics make it likely that populations will be genetically structured, even within continents. In North America, Gadwalls migrate within four delineated flyways (Atlantic, Mississippi, Central, and Pacific; Fig. 1), and most individuals that breed within a given flyway migrate to wintering grounds within that same flyway 


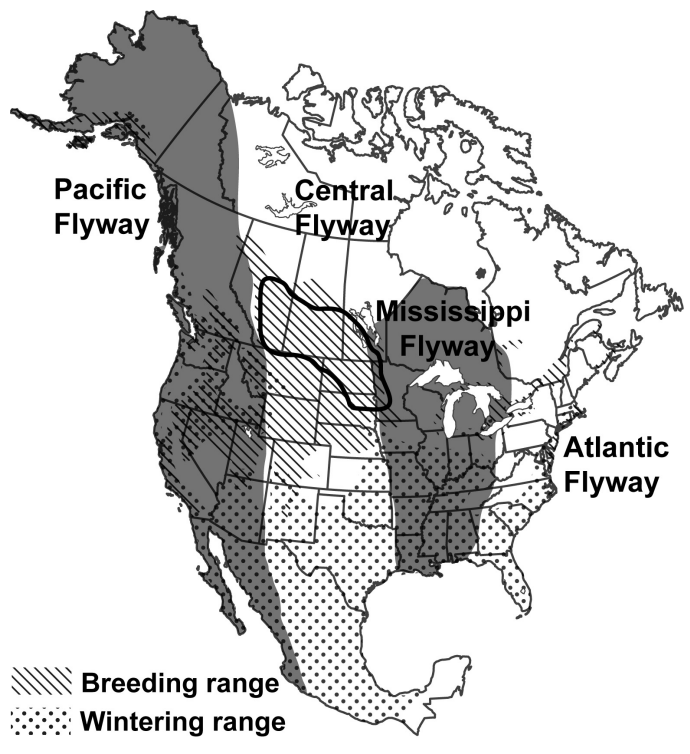

FIG. 1. North American breeding and wintering distribution of the Gadwall (from LeSchack et al. 1997). Migratory flyways are labeled and indicated by differences in shading (from Baldassarre and Bolen 1994); the Prairie Potholes Region is outlined by a solid black line (from Bellrose 1976).

(Bellrose 1976). Migratory flyways may contribute to the partitioning of genetic variation among populations (Anderson et al. 1992, Esler 2000). Comparing mtDNA sampled from different flyways has provided support for this possibility in Red-crested Pochards (Netta rufina; Gay et al. 2004), Lesser White-fronted Geese (Anser erythopus; Ruokonen et al. 2004), and Wood Ducks (Aix sponsa; Peters et al. 2005a). However, migratory flyways do not have discrete boundaries, and some Gadwalls that breed in the Central Flyway migrate to wintering areas within other flyways (Bellrose 1976). Interflyway migrants could potentially facilitate gene flow between distantly spaced populations.

Strong breeding philopatry, however, can give rise to population structure, even when different populations intermix on the wintering grounds (Rhodes et al. 1993, Esler 2000, Scribner et al. 2001, Kimura et al. 2002; see also Webster et al. 2002). In contrast to the sex-specific dispersal patterns of most birds, female ducks are philopatric to natal and previous breeding sites, whereas males disperse (Rohwer and Anderson 1988, Anderson et al. 1992). Pair formation generally occurs on the wintering grounds, where multiple populations intermix, and males follow their mates back to the female's breeding site (Rohwer and Anderson 1988). Therefore, the maternally inherited mtDNA is especially likely to be structured among duck populations (Tiedemann et al. 1999, Scribner et al. 2001, Gay et al. 2004, Pearce et al. 2005).

In several species of waterfowl, mtDNA is not structured among flyways or among populations (Cronin et al. 1996, Pearce et al. 2004). Historical population expansions may partially explain this lack of structure (Pearce et al. 2004, 2005). There are two reasons to predict a historical expansion in North American Gadwalls. First, environmental changes during the last glacial episode probably had a major effect on Gadwalls. More than $90 \%$ of North American Gadwalls breed in the Prairie Pothole Region of the Central Flyway (Canadian Wildlife Service 2005; U.S. Fish and Wildlife Service 2005a, b; Fig. 1), and this region was covered by ice during the last glacial maximum. In fact, glacial ice that completely melted only 9,000 years ago created the abundant wetlands that now provide excellent waterfowl habitat in that region (Pielou 1991). Therefore, Gadwalls must have colonized their primary North American breeding range after glacial retreat. Second, using an mtDNA phylogeny of the genus Anas, Johnson and Sorenson (1999) reconstructed the ancestral area of Gadwalls to be in Eurasia, which suggests that Gadwalls recently colonized North America. Under this hypothesis, a population expansion must have occurred to account for the large population size and widespread distribution of Gadwalls in North America.

North American Gadwalls have also experienced population and range expansions during the past century (LeSchack et al. 1997). Since 1955, the Canadian Wildlife Service (2005) and the U.S. Fish and Wildlife Service (2005a) have counted breeding waterfowl along traditional transects that cover most of the Gadwall's Central Flyway distribution. Within the traditional survey area (which also includes Alaska), the Gadwall population has increased at an average rate of $2.5 \%$ per year (Canadian Wildlife Service 2005). Breeding populations have also increased in size and range in the Pacific Flyway (Canning and Herman 1983, U.S. Fish and Wildlife Service 2005b), and breeding Gadwalls only recently colonized the Atlantic Flyway (Henny and 
Holgersen 1974). Thus, contemporary and historical expansions have likely contributed to the partitioning of genetic variation in this species.

The primary objective here was to examine population genetic structure in North American Gadwalls. Specifically, we tested the hypothesis that female breeding philopatry and fidelity to migratory flyways has contributed to the partitioning of mtDNA variation. In addition, we tested the hypothesis that Gadwalls experienced a historical population expansion in North America. Early in the sampling stage, however, we found multiple Gadwall haplotypes that were more closely related to Falcated Duck (Anas falcata) haplotypes (designated "clade B") than to the majority of Gadwall haplotypes ("clade A"). The Gadwall and Falcated Duck are each other's closest phylogenetic relatives (Johnson and Sorenson 1999, Peters et al. 2005b), but finding clade B haplotypes in North America was surprising, because the Falcated Duck is restricted to eastern Asia (eastern Russia, Japan, northern China, and Mongolia). Therefore, a second goal of the present study was to estimate the frequency of clade B haplotypes, and to test hypotheses regarding genealogical relationships and historical demography within clade B.

\section{Methods}

Sample collection. - We sampled at least 12 individuals from each of 14 Gadwall populations in North America. Each population was assigned to one of the following three categories: "known breeding," "putative breeding," or "nonbreeding" (Appendix). Known breeding populations included samples collected from nests, broods (one representative per brood), adult females and juveniles trapped between 22 May and 23 August, or individuals shot during the hunting season but unlikely to have migrated (the first and second primaries had not developed beyond the blood quill stage; see Krapu 2000). We sampled seven known breeding populations: North Dakota (ND); Saskatchewan (SK); Alberta (AB); Utah (UT); Washington (WA); Klamath Basin, California (CAkl); and Central Valley, California (CAcv). Three populations were designated as "putative breeding" because some individuals were collected in September, after the onset of migration but before peak migration, including
Quebec (QC), Manitoba (MB), and south-coastal Alaska (AKsc). Nonbreeding populations included adult males, adult females, and juveniles sampled during or after peak migration: Maritime Provinces (MP; Prince Edward Island, Nova Scotia, and New Brunswick), Delmarva Peninsula (DM; Delaware and Maryland), Arkansas (AR), and Kodiak Island, Alaska (AKko). Finally, we sampled 44 individuals from additional widespread locations, for a total of 348 North American Gadwalls (Appendix).

Laboratory methods. - We extracted DNA from various sources (Appendix) using the DNeasy Tissue Kit (Qiagen, Valencia, California). We sequenced a 658-667 base-pair fragment of the mtDNA control region, including the hypervariable $5^{\prime}$ end, using primers L78 and H774 (Sorenson and Fleischer 1996, Sorenson et al. 1999). Polymerase chain reaction and sequencing followed standard protocols (see McCracken et al. 2001, Peters et al. 2005b). Eleven haplotypes were previously published (GenBank accession numbers: AY881776-78, AY881784-91; Peters et al. 2005b); we also included 12 published haplotypes from Eurasian Gadwalls (AY112944, AY881779-83, AY881792-96, AY881809; DonneGoussé et al. 2002, Peters et al. 2005b). All new sequences have been deposited in GenBank (DQ449086-422).

Phylogenetic methods.-We aligned controlregion sequences using SEQUENCHER, version 4.1 (Gene Codes Corporation, Ann Arbor, Michigan). To build phylogenetic trees, we used equally weighted maximum parsimony (MP) and maximum likelihood (ML) in PAUP*, version 4.0b10 (Swofford 1999). For tree searches, we included one representative of each unique Gadwall haplotype and one representative of each of four Falcated Duck haplotypes (Peters et al. 2005b). We also randomly chose one haplotype from American Wigeon (A. americana), Chiloe Wigeon (A. sibililatrix), and Eurasian Wigeon (A. penelope; Peters et al. 2005b), because this group is sister to the Gadwall-Falcated Duck clade (Johnson and Sorenson 1999). Finally, we included haplotypes from a Eurasian Wigeon (Peters et al. 2005b) and an American Black Duck (A. rubripes; McCracken et al. 2001) that were identical to putatively introgressed haplotypes found in Gadwalls (see below), and a randomly chosen Mallard (Anas platyrhynchos; McCracken et al. 2001). Following the topology of Johnson and Sorenson (1999), we rooted 
trees using the "mallard clade" haplotypes. For $\mathrm{MP}$, we conducted a heuristic search with treebisection-reconnection (TBR) branch-swapping and maximum trees set to 100,000 . For ML, we used an HKY $+I+\Gamma$ mutation model that was selected using Akaike's Information Criteria in MODELTEST, version 3.7 (Posada and Crandall 1998). The initial ML search was conducted using this model and a randomly chosen MP tree as a starting point. We then re-estimated parameters using the ML tree and repeated the search using those parameters. We repeated this process until tree scores and parameter estimates stabilized (Wilgenbusch and de Queiroz 2000). The final parameters included a transitionto-transversion (ti:tv) ratio of $10.2,74 \%$ invariant sites $(I)$, and a gamma distribution $(\Gamma)$ of 0.8 . We evaluated MP bootstrap support by conducting 1,000 pseudoreplicates and using a heuristic search with TBR branch-swapping and maximum trees set to 1,000. Finally, we constructed haplotype networks showing alternative evolutionary pathways using the median-joining algorithm in FLUXUS, version 4.1 (Bandelt et al. 1999; see Acknowledgments).

We tested alternative topologies for clade B that were generated under different hypotheses regarding the cause of lineage sharing. If this shared lineage is explained by mtDNA introgression from Falcated Ducks into Gadwalls, we predicted that Gadwall clade B haplotypes would be derived from (i.e., nested within) Falcated Duck haplotypes (the observed ML tree; see below). We compared that topology to an ML tree constrained to having Falcated Duck haplotypes a monophyletic group nested within Gadwall clades, which might be expected if Falcated Ducks recently diverged from a polymorphic Gadwall-like ancestor via peripheral isolation (e.g., Harrison 1991). We compared trees using a Shimodaira-Hasegawa $(\mathrm{SH})$ test with resampling-estimated log likelihood and 1,000 bootstrap replicates (Shimodaira and Hasegawa 1999).

Genetic diversity and population structure.-For each intensively sampled population, we calculated allelic richness, standardized to a sample size of 12 [ $r(12)]$, using RAREFAC (Petit et al. 1998). The parameter $r(12)$ is the average number of different haplotypes expected if 12 individuals were sampled (the smallest sample size among the 14 populations). We chose this measure of genetic diversity because allelic richness should reflect demographic processes better than other standard measures (Petit et al. 1998). Both clade A and clade B haplotypes were included in calculations. In addition, we calculated $r(12)$ and nucleotide diversity $(\pi$, the average pairwise difference among haplotypes, calculated in ARLEQUIN, version 2.0; Schneider et al. 2000) among all haplotypes within each clade.

We tested models of population structure using analyses of molecular variance (AMOVA; Excoffier et al. 1992) executed in ARLEQUIN (Schneider et al. 2000). First, we tested for structure between clade B Gadwall and Falcated Duck haplotypes. Second, we restricted analyses to clade A haplotypes and used genetic distances ( $\Phi$-statistics) to test for population structure at three hierarchical levels: among flyways, among populations within flyways, and within populations. (Clade B was excluded from analyses because the deep divergence between clades contributed disproportionately to within-population variation when using $\Phi$-statistics; data not shown.) For analyses of breeding populations, we included seven populations from the Central (ND, SK, and $\mathrm{AB}$ ) and Pacific flyways (UT, WA, CAcv, and $C A k 1)$. We then tested for structure among all 14 populations and three flyways: Eastern Flyway (QC, MP, DM), Central-Mississippi flyways (ND, MB, SK, AB, AR), and Pacific Flyway (UT, CAcv, CAkl, WA, AKsc, AKko). Third, because clade B could potentially be informative regarding population structure, we repeated the above analyses including haplotypes from both clades, but using conventional $F$-statistics so that only haplotype frequencies were considered. Finally, we performed an ad-hoc AMOVA to test for differences between Alaska (AKsc and AKko) and the remaining 12 populations at three hierarchical levels (between Alaska and "others," among populations within these two groups, and within populations). To determine which populations were genetically differentiated, we calculated pairwise $\Phi_{S T}$ (clade A only) and $F_{S T}$ (clade A and clade B) among all populations (including Eurasia) in ARLEQUIN.

Population demography. - We tested for signatures of historical population expansions for clades A and B using the coalescent methods implemented in LAMARC, version 2.0.2 (Kuhner et al. 1998, 2005). On the basis of results 
from MODELTEST (see above), we defined a mutation model that included a ti:tv ratio of 10.2 and two rates of substitution among sites (74\% of sites were invariant, and $26 \%$ were allowed to vary). We used a Bayesian approach to simultaneously estimate theta $\left(\theta=2 N_{e f} \mu\right.$; where $N_{e f}$ is the effective number of females and $\mu$ is the neutral mutation rate) and growth $\left(\theta_{t}=\theta_{0} \mathrm{e}^{-g t}\right.$; where $\theta_{0}$ is the current effective population size scaled to $\mu, \theta_{t}$ is the effective population size at time $t$, and $g$ is the scaled exponential growth rate). On the basis of preliminary runs, we defined uninformative priors for $\theta(0.00001-1)$ that included the entire posterior distribution for clade A. Because the posterior distribution of $\theta$ for clade $B$ had a distinct peak but a flat tail that continued indefinitely (data not shown), we used the same priors as used for clade A. For the scaled exponential growth rate $(g)$, we used the maximum range of priors $(-5,000$ to 15,000). We also randomly subsampled 19 clade A haplotypes (the number of clade B haplotypes that we found; $n=20$ replicates) to evaluate how sensitive the results were to differences in sample sizes. For final analyses, we ran 5 million steps in a single chain that followed a burn-in period of 100,000 steps; analyses were repeated with different random-number seeds to check that multiple runs gave similar parameter estimates.

\section{Results}

Phylogenetic analyses. - Among the 348 North American Gadwalls sequenced for mtDNA, we found 31 different haplotypes that generally clustered into two main clades. Clade A contained 27 different haplotypes and 328 (94.3\%) of the North American individuals sequenced, as well as 11 of the 12 individuals sequenced from Eurasia (Fig. 2A). Clade B contained three different haplotypes sampled from 19 individuals (5.5\% of North American Gadwalls) that clustered with, but were not shared with, Falcated Ducks (Figs. 2 and 3). Cytochrome- $b$ and ND2 sequences indicated that these divergent lineages were not an artifact of amplifying a nuclear copy of mtDNA (J. L. Peters and K. E. Omland unpubl. data). In addition, one Gadwall from South Dakota had a haplotype that was shared with an American Black Duck, and a European Gadwall had a haplotype shared with Eurasian Wigeons (Fig. 2A).
The ML topology suggested that Gadwall clade B haplotypes were a monophyletic group nested within Falcated Duck haplotypes $(-\ln L=$ 1732.1; Fig. 2A), and MP also supported this topology (length $=148$ steps). However, alternative MP topologies suggested that clade $B$ haplotypes were intermixed in a polyphyletic relationship between species (Fig. 2B). Furthermore, a monophyletic Falcated Duck nested within Gadwall was not a significantly worse fit $(-\ln L=1735.2$; SH-test, $P=0.1)$, and this tree was only one step longer than MP trees.

Genetic diversity.-Mean allelic richness $[r(12)]$ among the 14 populations was 4.14 (95\% CI: 3.64 to 4.65; Appendix). Allelic richness was highest within the Utah and North Dakota breeding populations and the Arkansas and Delmarva nonbreeding populations. Washington, Quebec, and the two Alaskan populations had low allelic richness (below the $95 \%$ confidence interval). It is noteworthy that breeding and putative breeding populations near the center of North America tended to have higher allelic richness than those near the periphery (Appendix). Overall, clade A had higher allelic richness than clade B $[r(12)=4.58$ and 2.26, respectively], but the two clades had comparable nucleotide diversity $(\pi=0.0013$ and 0.0010 , respectively).

Population structure.-Gadwall clade B haplotypes differed from Falcated Duck haplotypes by 1 to 8 base pairs (Fig. 3), and these haplotypes were strongly structured between species (AMOVA, $\Phi_{S T}=0.67, \mathrm{df}=1, P<0.00001$ ). We found clade B in 10 of the 14 intensively sampled populations, including geographically disparate locations such as Alaska and the east and west coasts (Fig. 4). Within populations, the frequency of clade B ranged from $0.0 \%$ (e.g., Washington, Maritime Provinces) to $13.3 \%$ (Quebec), and the mean frequency was 5.5\% (95\% CI: $3.2 \%$ to $7.9 \%$ ). Among the known breeding populations, we found clade B in both the Central and Pacific flyways $(0.0-5.6 \%$ and $0.0-9.1 \%$, respectively), and 3 of the 12 known breeding individuals (25\%) from the Atlantic Flyway had clade B (Fig. 4; Appendix).

Clade A variation was not partitioned between the Central and Pacific flyway breeding populations, but $5.5 \%$ of the variation was partitioned among populations within flyways (Table 1A). Including all populations in analyses, variation among the three flyways did not 


\section{(A) ML topology}

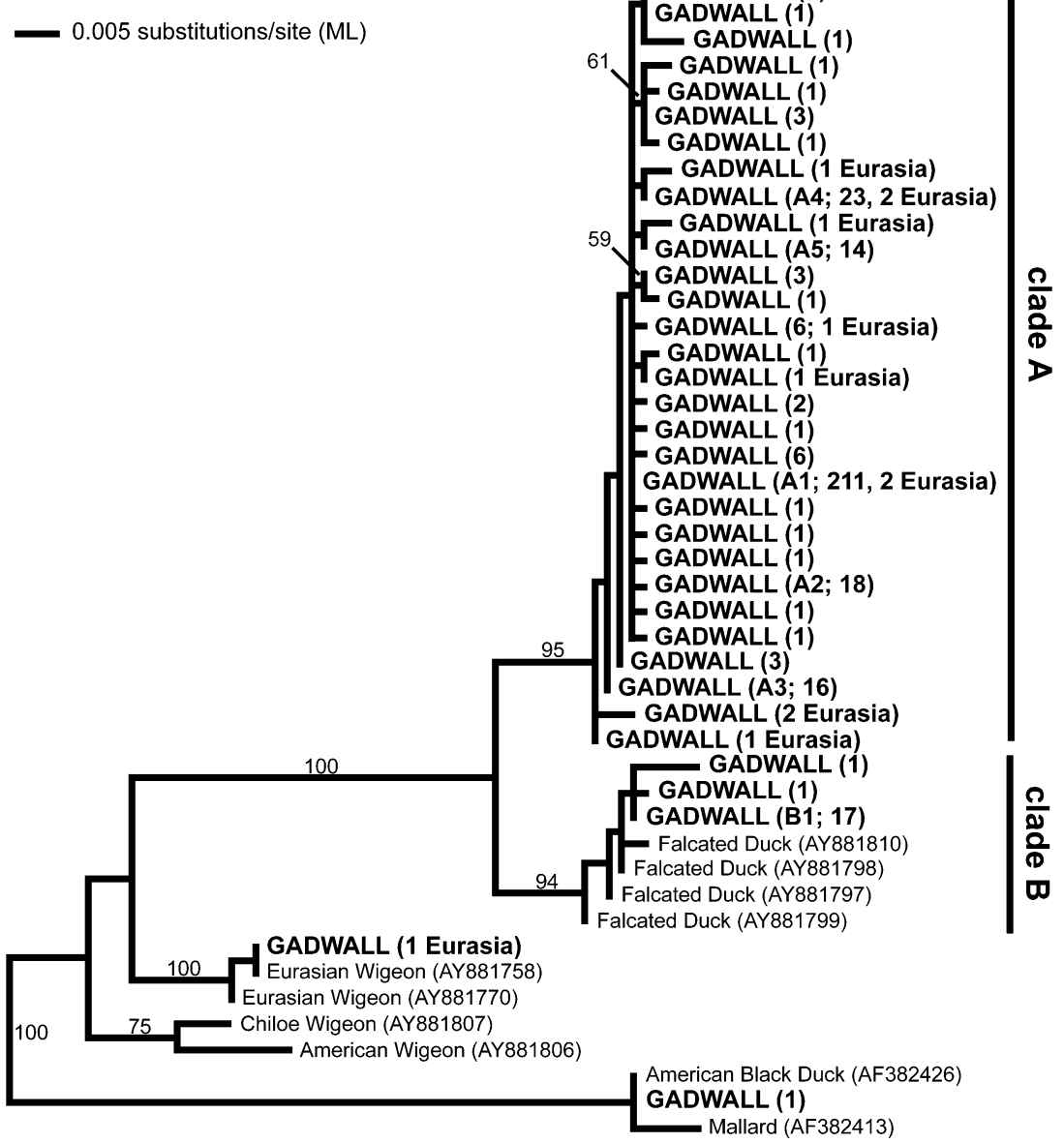

GADWALL (5)

GADWALL (3)

GADWALL (2)

GADWALL (1)

ADWALL (3)

GADWALL (1)

GADWALL (A5; 14)

GADWALL (3)

GADWALL (1)

GADWALL (2)

GADWALL (1)

GADWALL (A1; 211, 2 Eurasia)

GADWALL (1)

GADWAD

(B) Alternative MP topologies for Clade B

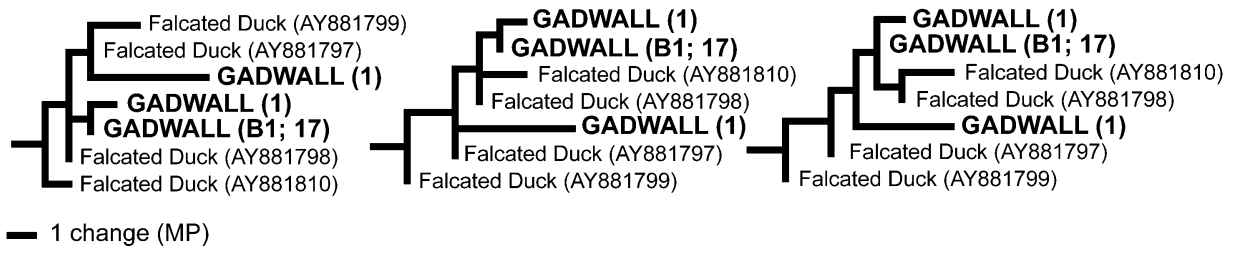

Fig. 2. (A) Maximum-likelihood (ML) tree $(-\ln L=1732.1)$ that is the same length as the maximum-parsimony $(\mathrm{MP})$ trees (length $=148$ steps; $>100,000$ equally parsimonious trees; most MP trees supported a monophyletic wigeon group; see Peters et al. 2005b.) Numbers above branches indicate MP bootstrap support; the six most common haplotypes are labeled A1-A5 and B1. Note that clade B Gadwalls are nested within Falcated Ducks. (B) Alternative MP topologies for clade B that show polyphyletic relationships between Gadwall and Falcated Duck haplotypes. 
Clade A

Clade B

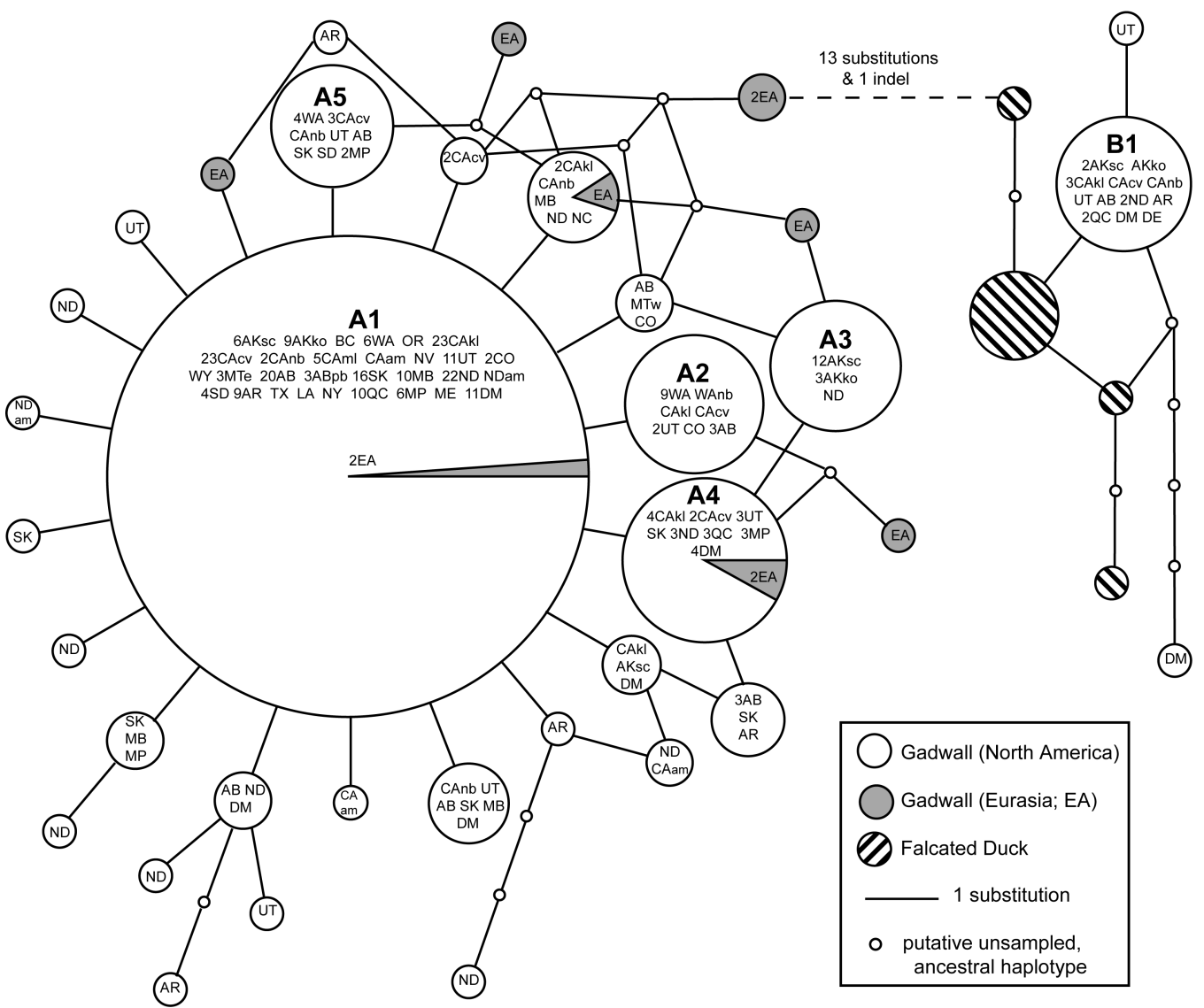

FIG. 3. Parsimony networks showing alternative connections among Gadwall and Falcated Duck haplotypes. The six most common haplotypes are labeled A1-A5 and B1 (see also Fig. 2). Additional labels indicate the number of individuals (if $>1$ ) and the populations from which each was sampled (see Appendix for population codes).

TABLE 1. Analysis of molecular variance among known breeding populations (Central and Pacific flyways). (A) $\Phi$-statistics restricted to clade A. (B) F-statistics include clade A and clade B haplotypes.

\begin{tabular}{|c|c|c|c|c|c|c|}
\hline Source of variation & $\mathrm{df}$ & $\begin{array}{l}\text { Sum of } \\
\text { squares }\end{array}$ & $\begin{array}{c}\text { Variance } \\
\text { components }\end{array}$ & $\begin{array}{l}F \text {-statistics/ } \\
\Phi \text {-statistics }\end{array}$ & $\begin{array}{l}\text { Percentage of } \\
\text { variation (\%) }\end{array}$ & $P$ \\
\hline \multicolumn{7}{|l|}{ (A) Clade A only } \\
\hline Among flyways & 1 & 0.87 & -0.001 & $\Phi_{C T}=-0.003$ & -0.34 & 0.4 \\
\hline Among populations & 5 & 4.75 & 0.022 & $\Phi_{S C}=0.054$ & 5.46 & $<0.00001$ \\
\hline Within populations & 180 & 68.23 & 0.379 & $\Phi_{S T}=0.051$ & 94.88 & $<0.00001$ \\
\hline \multicolumn{7}{|c|}{ (B) Clade A and clade B } \\
\hline Among flyways & 1 & 0.51 & -0.003 & $F_{C T}=-0.010$ & -0.98 & 0.6 \\
\hline Among populations & 5 & 3.78 & 0.017 & $F_{S C}=0.056$ & 5.62 & $<0.00001$ \\
\hline Within populations & 189 & 54.72 & 0.290 & $F_{S T}=0.046$ & 95.36 & $<0.00001$ \\
\hline
\end{tabular}




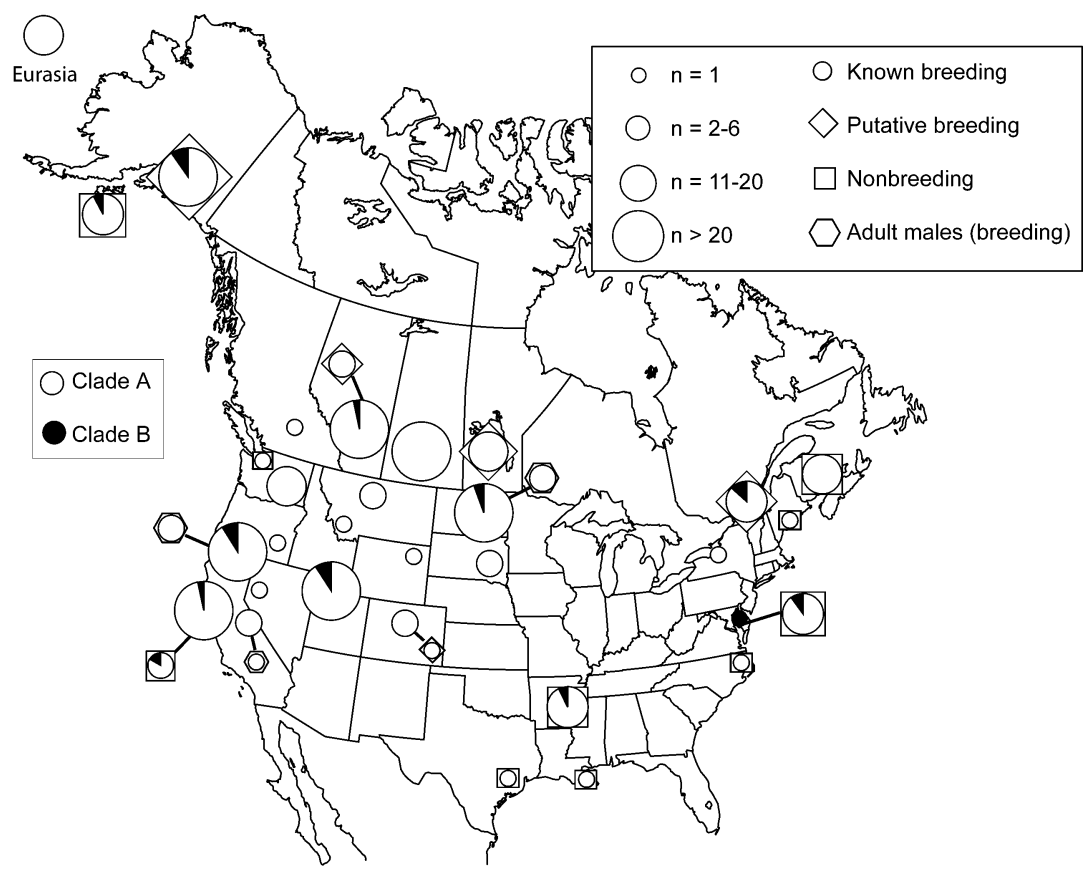

FIG. 4. Distributions of clades A and B were both broadly overlapping and geographically widespread.

account for any of the observed genetic variation, but variation among populations within flyways accounted for $14 \%$ of the variation (Table 2A). Including clade B haplotypes and using conventional $F$-statistics did not qualitatively change these results (Tables $1 \mathrm{~B}$ and $2 \mathrm{~B}$ ).

Pairwise $\Phi_{S T}$ values indicated that only Washington (WA) and south-coastal Alaska (AKsc) were well differentiated from other populations (Table 3). Whereas haplotype A1 was the most common haplotype within 12 of the 14 populations $(61 \%$ of all North American Gadwalls had that haplotype), A2 and A3 were the most common haplotypes in WA and AKsc, respectively (Fig. 5). Haplotype A2 was sequenced from $47 \%$ of breeding individuals from WA but was rare in other populations (2.4\% of non-Washington individuals; A2 was never found east of Colorado and Alberta; Fig. 5). Restricting analyses to clade A, WA differed significantly from four of the six breeding populations and three of the seven remaining

TABLE 2. Analysis of molecular variance among all populations (known breeding, putative breeding, and nonbreeding; Atlantic, Central, and Pacific flyways). (A) $\Phi$-statistics restricted to clade A. (B) F-statistics include clade A and clade B haplotypes.

\begin{tabular}{|c|c|c|c|c|c|c|}
\hline Source of variation & $\mathrm{df}$ & $\begin{array}{l}\text { Sum of } \\
\text { squares }\end{array}$ & $\begin{array}{c}\text { Variance } \\
\text { components }\end{array}$ & $\begin{array}{l}F \text {-statistics/ } \\
\Phi \text {-statistics }\end{array}$ & $\begin{array}{l}\text { Percentage of } \\
\text { variation }(\%)\end{array}$ & $P$ \\
\hline \multicolumn{7}{|l|}{ (A) Clade A only } \\
\hline Among flyways & 2 & 2.50 & -0.005 & $\Phi_{C T}=-0.010$ & -1.03 & 0.6 \\
\hline Among populations & 11 & 17.88 & 0.061 & $\Phi_{S C}=0.137$ & 13.79 & $<0.00001$ \\
\hline Within populations & 273 & 105.76 & 0.387 & $\Phi_{S T}=0.128$ & 87.24 & $<0.00001$ \\
\hline \multicolumn{7}{|l|}{ (B) Clade A and clade B } \\
\hline Among flyways & 2 & 1.80 & 0.0008 & $F_{C T}=0.003$ & 0.26 & 0.2 \\
\hline Among populations & 11 & 8.84 & 0.024 & $F_{S C}=0.076$ & 7.60 & $<0.00001$ \\
\hline Within populations & 290 & 84.38 & 0.291 & $F_{S T}^{s c}=0.079$ & 92.14 & $<0.00001$ \\
\hline
\end{tabular}




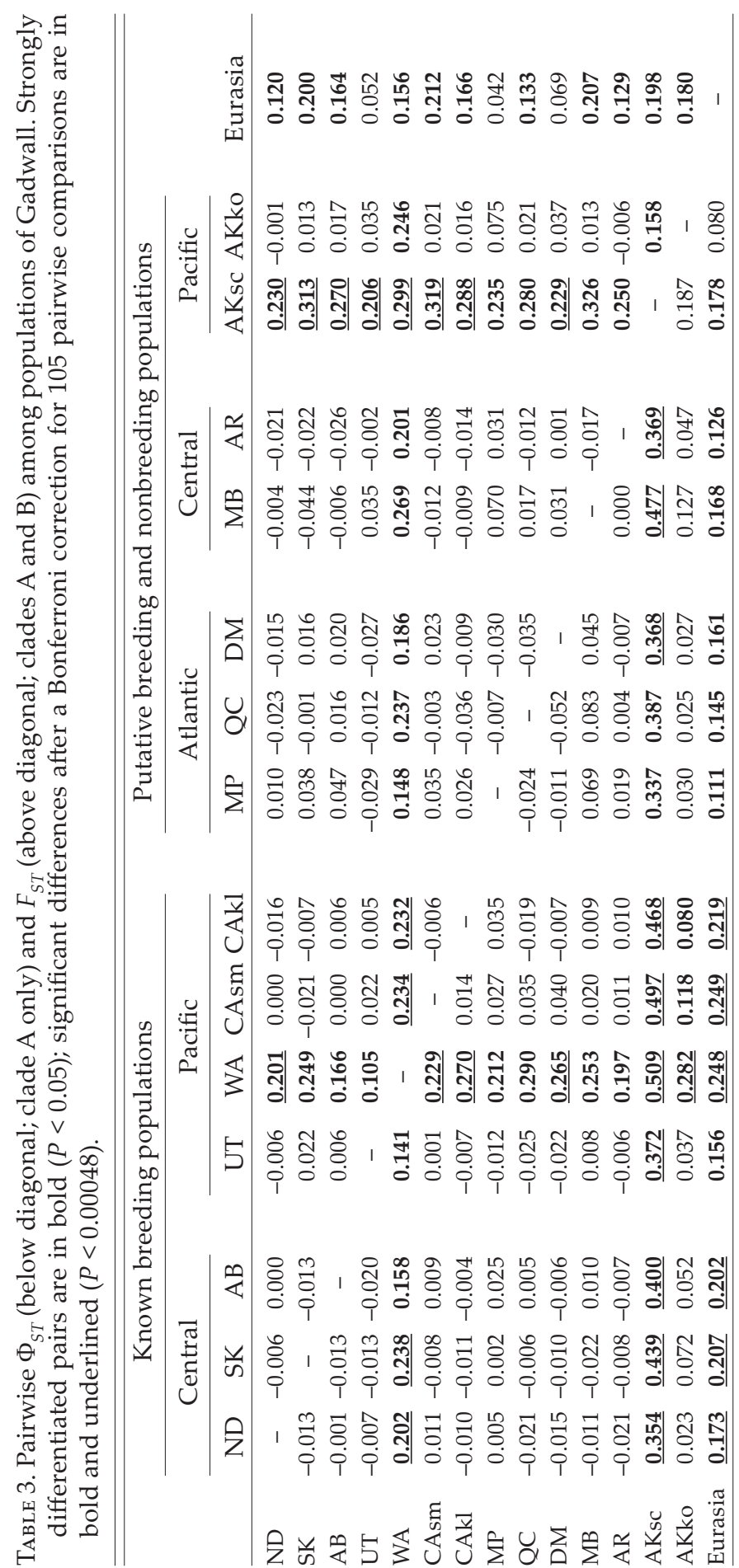




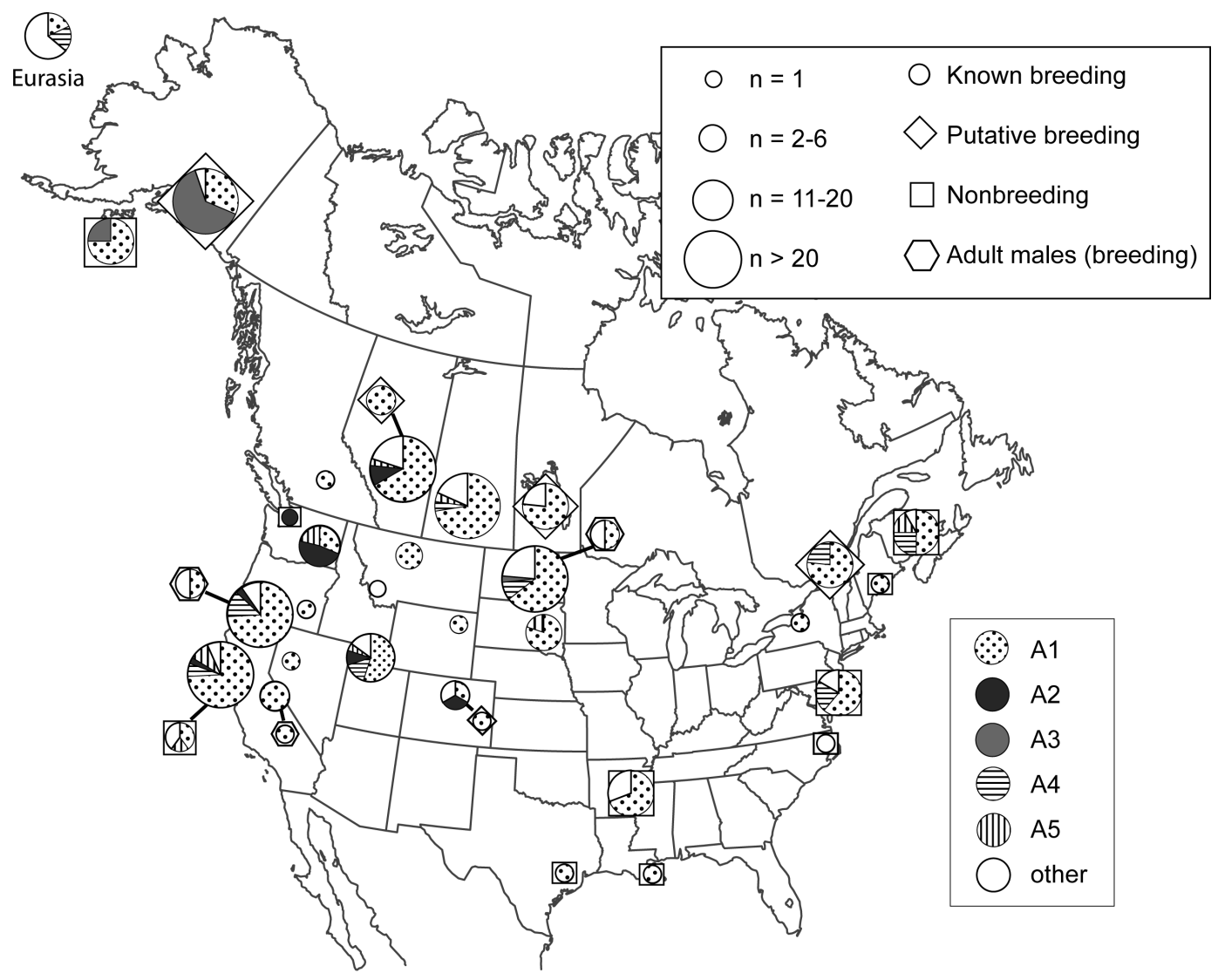

Fig. 5. Distributions of the five most common clade A haplotypes (i.e., $>10$ haplotypes sampled; see Fig. 3). Note the widespread distributions of haplotypes A1, A4, and A5, and the more restricted distributions of A2 and A3 (especially in Washington and Alaska, respectively).

populations after a Bonferroni correction (Table 3). In AKsc, A3 was found in $57 \%$ of the samples (Fig. 5). This haplotype was also relatively common in AKko (23\%) but was found in only one individual outside of Alaska (i.e., ND; $0.3 \%$ of all non-Alaskan individuals). Population AKsc differed significantly from 10 of the 13 populations after a Bonferroni correction $\left(\Phi_{S T}\right.$; Table 3). Although AKko did not differ significantly from other populations (except WA), $29.6 \%$ of clade A variation was partitioned between the two Alaskan populations and the remaining populations $(P=0.01 ; \Phi$-statistics $)$, whereas only $3.8 \%$ of the variation was partitioned among populations within these two groups $(P$ $=0.0001)$. Finally, Eurasian Gadwalls tended to be differentiated from North American populations, and differences were significant for 5 of the 14 pairwise comparisons (Table 3). Including clade B haplotypes in analyses and calculating $F_{S T}$ did not dramatically change the observed patterns, except that there were fewer significant differences after applying a Bonferroni correction (Table 3).

Population demography.-Demographic analyses indicated population growth for clade A (Fig. 6). The posterior distribution of $g$ peaked at 3,500 , and the $95 \%$ CI did not overlap zero (95\% CI: 1,200 to 12,000$)$. Therefore, we rejected the null hypothesis of a long-term stable population size. By contrast, the posterior distribution of $g$ for clade B peaked at -210 , which suggests a population decline, and the $95 \%$ CI overlapped zero growth (95\% CI: $-2,200$ to 13,000$)$. The broad confidence interval for clade B was a result of a flat tail in the posterior distribution (Fig. 6). Regardless, the signatures of growth for clades A and B were markedly different, 


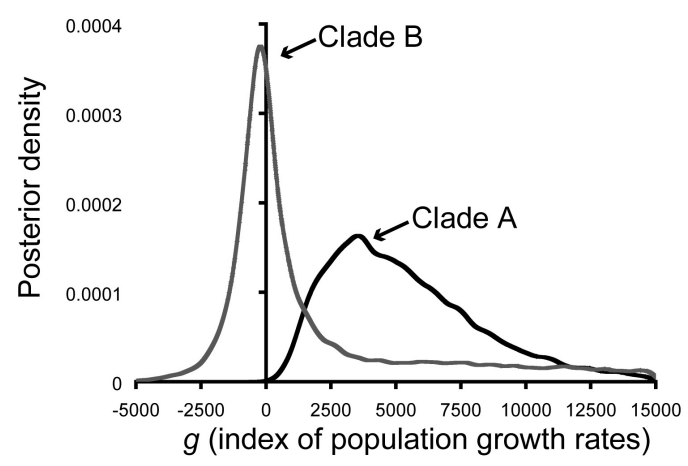

Fig. 6. Posterior distributions of population growth rates $(g)$ estimated for Gadwall. Clade A has experienced historical population growth, whereas clade B seems to have experienced a more stable population size.

which suggests that these clades most likely experienced different demographic histories. This difference cannot be explained by unequal sample sizes; subsampling 19 haplotypes from clade A, $g$ averaged $10,000(n=20$ replicates; range: $4,600-13,000$ ), and the $95 \%$ CI did not overlap the value of $g$ estimated for clade B in any of those replicates. The distinctly star-like parsimony network for clade A also suggests a rapid population expansion compared with the clade B network (Fig. 3).

\section{Discussion}

Mitochondrial DNA paraphyly. - We found two distinct mtDNA lineages in Holarctic Gadwalls (clades A and B). Clade A was common in both North America and Eurasia. By contrast, clade B was relatively uncommon in North America and was not present among the 12 Eurasian Gadwalls sampled. Clade B was shared with the Asian Falcated Duck, but no haplotypes were shared between species. This absence of shared haplotypes suggests that clade B Gadwalls and Falcated Ducks have been diverging for some time ("allotypy"; Omland et al. 2006). Furthermore, clade B was geographically widespread in North America (Fig. 4), and one of the clade B haplotypes (B1) was the fourth most common haplotype overall (Fig. 3). Assuming a breeding population size of 2.4 million North American Gadwalls in 2005 (Central and Pacific flyways; U.S. Fish and Wildlife Service 2005a, b), and assuming that the frequency of clade
B was between $3.2 \%$ and $7.9 \%$ (95\% CI of the mean), we estimated that between 77,000 and 190,000 North American Gadwalls had clade B haplotypes. Thus, clade B haplotypes are strongly incorporated into the Gadwall gene pool, and recent, ongoing hybridization with the Falcated Duck is not sufficient to explain this shared lineage.

Despite similar distributions in North America, clades A and B most likely have different demographic histories. We found strong evidence that clade A underwent a historical demographic expansion, whereas clade $B$ seems to have experienced a population decline or a more stable population size. These contrasting histories suggest that the broadly overlapping geographic distributions resulted from recent admixture of lineages descended from different source populations (see Quinn 1992, Fry and Zink 1998, Lambert et al. 2002, Ruokonen et al. 2004).

Overall, the observed pattern of lineage sharing seems most consistent with ancient introgression of Falcated Duck mtDNA into the Gadwall gene pool (perhaps from a single hybridization event). This interpretation is especially supported by the topology of the ML tree, which shows Gadwall clade B haplotypes to be a monophyletic group nested within Falcated Duck haplotypes. The different demographic histories of the clades are also consistent with ancient introgression. One possible scenario is that clade B introgression occurred while Gadwall populations were expanding, and this expansion could have facilitated the dispersion of clade B across North America. An alternative scenario is that Gadwalls recently colonized North America from Eurasia (see below), and one or more of the founding females carried clade B haplotypes. This latter possibility seems less likely, because simultaneous colonization by both clades should have resulted in similar signatures of population growth (although note the broad overlap in growth rates; Fig. 6). Regardless, introgression of Falcated Duck mtDNA following ancient hybridization seems sufficient to explain clade B haplotypes in North American Gadwalls.

An alternative to introgression is that the Gadwall and Falcated Duck recently diverged from a polymorphic ancestor that contained both mtDNA lineages. Widespread species with structured populations can give rise to new 
species through peripatric or parapatric speciation, and mtDNA from the parental population will likely be paraphyletic to that of the daughter population (Harrison 1991, Omland 1997, Funk and Omland 2003). Under this scenario, we would expect Falcated Duck haplotypes to be nested within Gadwall haplotypes, and we could not statistically reject that tree topology. Furthermore, the ancestral polymorphism hypothesis does not predict that shared lineages will be found in sympatry (Hare and Avise 1998, Masta et al. 2002, Sefc et al. 2005) and, in that regard, it may be a better explanation of paraphyly in this group. However, given the data and analyses presented, either hybridization or incomplete lineage sorting is sufficient to explain the shared lineage between Gadwalls and Falcated Ducks. Increased sampling of Falcated Ducks and additional loci are needed to statistically test these alternative hypotheses.

We also found Gadwall haplotypes that were shared with American Black Ducks (McCracken et al. 2001) and Eurasian Wigeons (Peters et al. 2005b). The Gadwall is known to hybridize with and produce fertile offspring with these species or close allies of these species (Johnsgard 1960). These haplotypes were sampled from wings, and close examination of those wings revealed no qualitative differences from other Gadwall wings of the same sex and age class. There was no obvious indication of a hybrid ancestry. Therefore, it is unlikely that these individuals were $\mathrm{F} 1$ hybrids or even F2 backcrosses (a close examination of hybrid wing patterns or an analysis of nuclear loci is needed to fully discount these possibilities). These haplotypes demonstrate mtDNA introgression between highly divergent species (see also Cronin et al. 1996); it is possible that drift or selection could drive such introgressed mtDNA to high frequencies or even fixation.

Population structure. - Migratory flyways did not contribute to the partitioning of genetic variation within North American Gadwalls, and this result is similar to patterns found in other species of waterfowl (Cronin et al. 1996, Pearce et al. 2004; but see Gay et al. 2004, Peters et al. 2005a). One possible explanation of this lack of structure is that winter intermixing facilitates female dispersal, even though only a small percentage of Gadwalls move between flyways during seasonal migrations (Bellrose 1976). Breeding Gadwalls are about an order of magnitude more abundant in the Central
Flyway than in the Pacific Flyway (U.S. Fish and Wildlife Service 2005a, b), and even a small fraction of Central Flyway breeders migrating to the Pacific Flyway could result in extensive intermixing. If the gregarious behavior of Gadwalls results in females migrating with foreign flocks to new breeding areas, extensive intermixing during winter could contribute to high genetic similarity between breeding populations from different flyways.

The predominant pattern we found was a general lack of genetic structure among both breeding and nonbreeding populations of North American Gadwalls. Although female philopatry is well established in waterfowl, the extent of short-distance and long-distance dispersal is not known. Competition for breeding resources and fluctuations in local breeding conditions likely drive regular short-distance and even occasional long-distance dispersal. For example, some waterfowl "over-fly" previous breeding sites to more northern locations when local conditions decline from one year to the next (Johnson and Grier 1988). Differences between breeding philopatry and natal philopatry could also explain the general lack of population structure. Whereas $33 \%$ to $49 \%$ of adult female Gadwalls returned to previous breeding areas in subsequent years, only $7 \%$ to $9 \%$ of hatch-year females returned to natal areas (reviewed in Anderson et al. 1992). Therefore, females seem to disperse regularly, but more information is needed on dispersal distances for Gadwalls and other species of waterfowl. However, even regular short-distance dispersal can accumulate into substantial gene flow between distant populations over evolutionary time.

Although it is possible that female dispersal homogenizes widely dispersed populations, we found that the Washington breeding population and the south-coastal Alaskan population (presumably breeding) were well differentiated in mtDNA. The Alaskan population is widely disjunct from the Gadwall's core breeding range (Fig. 1), and this disjunction may inhibit female-mediated gene flow (McCracken et al. 2001, Peters et al. 2005a). In addition, Gadwalls are present in Alaska throughout the year, which suggests that this population may be sedentary or only partially migratory. Indeed, the putative breeding (AKsc) and nonbreeding (AKko) populations from Alaska were not strongly differentiated, which suggests the 
genetic autonomy of Alaskan Gadwalls, at least in regard to female dispersal.

In contrast to the Alaskan population, the Washington breeding population seems continuous with the core breeding range, and potential geographic barriers to gene flow are not obvious. Furthermore, most Gadwalls that breed in Washington migrate to California's Central Valley, where they presumably intermix with other populations (Bellrose 1976). The strong differentiation could have resulted from a shift in haplotype frequencies associated with a breeding-range expansion into Washington (Hewitt 1996, Ibrahim et al. 1996). Consistent with that hypothesis, Washington Gadwalls had fewer haplotypes than any other breeding population sampled, but a number comparable to that of the putative breeding population in Quebec, a recently established population (LeSchack et al. 1997). Although breeding has only recently been documented in western Washington (Canning and Herman 1983), it is not clear whether Gadwalls also recently began breeding in the Columbia Basin (eastern Washington), where our samples were collected.

Using coalescent methods, we found strong support for a historical population expansion of clade A in North America. This historical expansion, coupled with recent population and range expansions, likely had a major effect on the partitioning of genetic variation among North American Gadwalls. The likelihood of any given haplotype becoming established in a recently founded population will be a function of its relative abundance in the parental population, the number of founders, and subsequent gene flow (see Ibrahim et al. 1996). In the present study, we found that $61 \%$ of all sampled Gadwalls shared a common haplotype (A1); therefore, this haplotype has a high probability of being carried by even a small number of founders. For example, $67 \%$ of known breeding samples from recently established populations in the Atlantic Flyway had that haplotype. If Gadwalls recently colonized much of their current distribution from a single source, finding A1 as the most common haplotype in most populations would not be surprising, even if gene flow is rare. Furthermore, random sampling of haplotypes during colonization could explain the strong differentiation of Washington and Alaska. In that regard, a recent expansion may be a better explanation of the complex population structure (or lack thereof) in North American Gadwalls (see also Pearce et al. 2004, 2005). Selection favoring different haplotypes in different habitats could also have contributed to these patterns.

Finally, North American and Eurasian Gadwalls tended to be well differentiated in mtDNA, which suggests that female-mediated gene flow is restricted. The Holarctic Mallard is also strongly structured between hemispheres, but differences were more pronounced in that species (Kulikova et al. 2005). The more shallow genealogy in Gadwalls suggests a more recent divergence between hemispheres (see also Pearce et al. 2005), which might be explained by a recent colonization of North America (see Johnson and Sorenson 1999). Consistent with that hypothesis, the ML topology placed Eurasian haplotypes near the root of clade A, which suggests that North American haplotypes are derived. Furthermore, the signature of population growth that we found in clade A is consistent with colonization of North America by a small number of individuals. However, many species from the Northern Hemisphere show evidence of recent expansion from glacial refugia (Hewitt 2000, Lessa et al. 2003). Larger sample sizes for Eurasia, multiple independent loci, and statistical analyses that account for the randomness of genetic processes are needed to test hypotheses regarding colonization history (Rosenberg and Nordborg 2002, Knowles 2004).

Conclusions.-More rigorous comparisons with Eurasian Gadwalls and Falcated Ducks, including a comparison of nuclear loci, are needed to better understand the patterns of genetic variation in North American Gadwalls. Regardless, the weak mtDNA structure in North American Gadwalls, especially between migratory flyways, probably resulted from a combination of female-mediated gene flow and recent and historical expansions. However, the extent to which each of these contributed to weak population structure is not clear. Additional data and analyses are also needed to determine whether clade B is shared with Falcated Ducks as a result of mtDNA introgression or incomplete lineage sorting.

\section{AcKnowledgments}

We thank the following people and organizations for their participation with this study. Such broadscale sampling would not have 
been possible without the help of P. Padding, W. Martin, N. North, D. Mauser, D. Loughman, T. Hames, B. Olson, B. Emery, J. Jehl, Jr., L. Loos, K. Chodacheck, the Burke Museum of Natural History, University of Washington, and the Delaware Museum of Natural History. Collection, import, and export permits were issued by the U.S. Fish and Wildlife Service, Canadian Wildlife Service, North Dakota Game and Fish Department, Utah Division of Wildlife Resources, California Department of Fish and Game, and Washington Department of Fish and Wildlife. E. M. Humphries, A. Logie, and K. Doshi provided lab assistance. J. Bell and B. Alemi in the Department of Mathematics and Statistics at University of Maryland Baltimore County, provided computer resources for coalescent analyses. S. Freeland and N. Keulman also provided computer assistance. Two anonymous reviewers, B. Kondo and other members of the Omland lab, provided insightful comments on this manuscript. This research was supported by grants from Delta Waterfowl Foundation and Maryland Ornithological Society to J.L.P., and K.E.O. is supported by National Science Foundation grant DEB-0347083. For information on FLUXUS, see www.fluxus-engineering.com.

\section{Literature Cited}

Anderson, M. G., J. M. Rhymer, And F. C. Rohwer. 1992. Philopatry, dispersal, and the genetic structure of waterfowl populations. Pages 365-395 in Ecology and Management of Breeding Waterfowl (B. D. J. Batt, A. D. Afton, M. G. Anderson, C. D. Ankney, D. H. Johnson, J. A. Kadlec, and G. L. Krapu, Eds.). University of Minnesota Press, Minneapolis.

Avise, J. C. 2000. Phylogeography: The History and Formation of Species. Harvard University Press, Cambridge, Massachusetts.

Avise, J. C., R. T. Alisauskas, W. S. Nelson, and C. D. Ankney. 1992. Matriarchal population genetic structure in an avian species with female natal philopatry. Evolution 46: 1084-1096.

Avise, J. C., C. D. Ankney, and W. S. Nelson. 1990. Mitochondrial gene trees and the evolutionary relationship between Mallard and Black Ducks. Evolution 44:1109-1119.

Baldassarre, G. A., ANd E. G. Bolen. 1994. Waterfowl Ecology and Management. John Wiley and Sons, New York.
Bandelt, H.-J., P. Forster, And A. Röhl. 1999. Median-joining networks for inferring intraspecific phylogenies. Molecular Biology and Evolution 16:37-48.

Bellrose, F. C. 1976. Ducks, Geese and Swans of North America. Stackpole Books, Harrisburg, Pennsylvania.

Canadian Wildlife Service. 2005. Population status of migratory game birds in Canada: November 2005. Canadian Wildlife Service Waterfowl Committee, CWS Migratory Birds Regulatory Report Number 16, Ottawa, Ontario.

Canning, D. J., and S. G. Herman. 1983. Gadwall breeding range expansion into western Washington. Murrelet 64:27-31.

Cronin, M. A., J. B. Grand, D. Esler, D. V. Derksen, AND K. T. Scribner. 1996. Breeding populations of Northern Pintails have similar mitochondrial DNA. Canadian Journal of Zoology 74:992-999.

Donne-Goussé, C., V. Laudet, And C. Hänni. 2002. A molecular phylogeny of anseriformes based on mitochondrial DNA analysis. Molecular Phylogenetics and Evolution 23:339-356.

Drovetski, S. V., R. M. Zink, S. Rohwer, I. V. Fadeev, E. V. Nesterov, I. Karagodin, E. A. Koblik, And Y. A. ReD'Kin. 2004. Complex biogeographic history of a Holarctic passerine. Proceedings of the Royal Society of London, Series B 271:545-551.

Esler, D. 2000. Applying metapopulation theory to conservation of migratory birds. Conservation Biology 14:366-372.

Excoffier, L., P. E. Smouse, and J. M. Quattro. 1992. Analysis of molecular variance inferred from metric distances among DNA haplotypes: Application to human mitochondrial DNA restriction data. Genetics 131:479-491.

FRY, A. J., AND R. M. ZINK. 1998. Geographic analysis of nucleotide diversity and Song Sparrow (Aves: Emberizidae) population history. Molecular Ecology 7:1303-1313.

Funk, D. J., AND K. E. Omland. 2003. Specieslevel paraphyly and polyphyly: Frequency, causes, and consequences, with insights from animal mitochondrial DNA. Annual Review of Ecology, Evolution and Systematics 34:397-423.

Gay, L., P. Defos Du Rau, J.-Y. Mondain-Monval, AND P.-A. CRochet. 2004. Phylogeography of a game species: The Red-crested Pochard 
(Netta rufina) and consequences for its management. Molecular Ecology 13:1035-1045.

Hare, M. P., And J. C. Avise. 1998. Population structure in the American oyster as inferred by nuclear gene genealogies. Molecular Biology and Evolution 15:119-128.

Harrison, R. G. 1991. Molecular changes at speciation. Annual Review of Ecology and Systematics 22:281-308.

Henny, C. J., And N. E. Holgersen. 1974. Range expansion and population increase of the Gadwall in eastern North America. Wildfowl 25:95-101.

Hewit, G. M. 1996. Some genetic consequences of ice ages, and their role in divergence and speciation. Biological Journal of the Linnean Society 58:247-276.

Hewits, G. [M.] 2000. The genetic legacy of the Quaternary ice ages. Nature 405:907-913.

Ibrahim, K. M., R. A. Nichols, and G. M. HewitT. 1996. Spatial patterns of genetic variation generated by different forms of dispersal during range expansion. Heredity 77:282-291.

Johnsgard, P. A. 1960. Hybridization in the Anatidae and its taxonomic implications. Condor 62:25-33.

Johnson, D. H., AND J. W. Grier. 1988. Determinants of breeding distributions of ducks. Wildlife Monographs 100:1-37.

Johnson, K. P., AND M. D. Sorenson. 1999. Phylogeny and biogeography of dabbling ducks (Genus: Anas): A comparison of molecular and morphological evidence. Auk 116:792-805.

Kimura, M., S. M. Clegg, I. J. Lovette, K. R. Holder, D. J. Girman, B. Milá, P. Wade, AND T. B. Smith. 2002. Phylogeographical approaches to assessing demographic connectivity between breeding and overwintering regions in a Nearctic-Neotropical warbler (Wilsonia pusilla). Molecular Ecology 11:1605-1616.

Knowles, L. L. 2004. The burgeoning field of statistical phylogeography. Journal of Evolutionary Biology 17:1-10.

Krapu, G. L. 2000. Temporal flexibility of reproduction in temperate-breeding dabbling ducks. Auk 117:640-650.

Kuhner, M. K., J. Yamato, P. Beerli, L. P. Smith, E. Rynes, E. Walkup, C. Li, J. Sloan, P. Colacurcio, and J. Felsenstein. 2005. LAMARC, version 2.0. University of
Washington, Seattle. [Online.] Available at evolution.gs.washington.edu/lamarc/index. html.

Kuhner, M. K., J. Yamato, and J. Felsenstein. 1998. Maximum likelihood estimation of population growth rates based on the coalescent. Genetics 149:429-434.

Kulikova, I. V., S. V. Drovetski, D. D. Gibson, R. J. Harrigan, S. Rohwer, M. D. Sorenson, K. Winker, Y. N. Zhuravlev, and K. G. MCCRACKen. 2005. Phylogeography of the Mallard (Anas platyrhynchos): Hybridization, dispersal, and lineage sorting contribute to complex geographic structure. Auk 122: 949-965.

Kulikova, I. V., Y. N. Zhuravlev, and K. G. McCracken. 2004. Asymmetric hybridization and sex-biased gene flow between Eastern Spot-billed Ducks (Anas zonorhyncha) and Mallards (A. platyrhynchos) in the Russian Far East. Auk 121:930-949.

Lambert, D. M., P. A. Ritchie, C. D. Millar, B. Holland, A. J. Drummond, and C. Baroni. 2002. Rates of evolution in ancient DNA from Adélie Penguins. Science 295:2270-2273.

LeSchack, C. R., S. K. McKnight, and G. R. Hepp. 1997. Gadwall (Anas strepera). In The Birds of North America, no. 283 (A. Poole, and F. Gill, Eds.). Academy of Natural Sciences, Philadelphia, and American Ornithologists' Union, Washington, D.C.

Lessa, E. P., J. A. Cook, And J. L. Patton. 2003. Genetic footprints of demographic expansion in North America, but not Amazonia, during the Late Quaternary. Proceedings of the National Academy of Sciences USA 100: 10331-10334.

Mallet, J. 2005. Hybridization as an invasion of the genome. Trends in Ecology and Evolution 20:229-237.

Masta, S. E., B. K. Sullivan, T. Lamb, and E. J. Routman. 2002. Molecular systematics, hybridization, and phylogeography of the Bufo americanus complex in Eastern North America. Molecular Phylogenetics and Evolution 24:302-314.

McCracken, K. G., W. P. Johnson, and F. H. Sheldon. 2001. Molecular population genetics, phylogeography, and conservation biology of the Mottled Duck (Anas fulvigula). Conservation Genetics 2:87-102.

Milot, E., H. L. Gibbs, and K. A. Hobson. 2000. Phylogeography and genetic structure of 
northern populations of the Yellow Warbler (Dendroica petechia). Molecular Ecology 9: 667-681.

Omland, K. E. 1997. Examining two standard assumptions of ancestral reconstructions: Repeated loss of dichromatism in dabbling ducks (Anatini). Evolution 51:1636-1646.

Omland, K. E., J. M. Baker, and J. L. Peters. 2006. Genetic signatures of intermediate divergence: Population history of Old and New World Holarctic Ravens (Corvus corax). Molecular Ecology 15:795-808.

Omland, K. E., C. L. Tarr, W. I. Boarman, J. M. Marzluff, and R. C. Fleischer. 2000. Cryptic genetic variation and paraphyly in ravens. Proceedings of the Royal Society of London, Series B 267:2475-2482.

Pearce, J. M., S. L. Talbot, M. R. Petersen, and J. R. REARICK. 2005. Limited genetic differentiation among breeding, molting, and wintering groups of the threatened Steller's Eiders: The role of historic and contemporary factors. Conservation Genetics 6:743-757.

Pearce, J. M., S. L. Talbot, B. J. Pierson, M. R. Petersen, K. T. Scribner, D. L. Dickson, and A. Mosbech. 2004. Lack of spatial genetic structure among nesting and wintering King Eiders. Condor 106:229-240.

Peters, J. L., W. Gretes, and K. E. Omland. 2005a. Late Pleistocene divergence between eastern and western populations of Wood Ducks (Aix sponsa) inferred by the "isolation with migration" coalescent method. Molecular Ecology 14:3407-3418.

Peters, J. L., K. G. McCracken, Y. N. Zhuravlev, Y. Lu, R. E. Wilson, K. P. Johnson, And K. E. OmLand. 2005b. Phylogenetics of wigeons and allies (Anatidae: Anas): The importance of sampling multiple loci and multiple individuals. Molecular Phylogenetics and Evolution 35:209-224.

Petit, R. J., A. el Mousadik, and O. Pons. 1998. Identifying populations for conservation on the basis of genetic markers. Conservation Biology 12:844-855.

Pielou, E. C. 1991. After the Ice Age: The Return of Life to Glaciated North America. University of Chicago Press, Chicago, Illinois.

Posada, D., AND K. A. CRandall. 1998. MODELTEST: Testing the model of DNA substitution. Bioinformatics 14:817-818.

Quinn, T. W. 1992. The genetic legacy of Mother Goose-Phylogeographic patterns of Lesser
Snow Goose Chen caerulescens caerulescens maternal lineages. Molecular Ecology 1: 105-117.

Rhodes, O. E., JR., L. M. SMith, AND R. K. Chesser. 1993. Temporal components of genetic variance in wintering and migrating American Wigeon. Canadian Journal of Zoology 71:2229-2235.

Rhymer, J. M., M. J. Williams, and M. J. Braun. 1994. Mitochondrial analysis of gene flow between New Zealand Mallards (Anas platyrhynchos) and Grey Ducks (A. superciliosa). Auk 111:970-978.

Rohwer, F. C., And M. G. Anderson. 1988. Female-biased philopatry, monogamy, and the timing of pair formation in migratory waterfowl. Pages 187-221 in Current Ornithology, vol. 5 (R. F. Johnston, Ed.). Plenum Press, New York.

Rosenberg, N. A., ANd M. Nordborg. 2002. Genealogical trees, coalescent theory and the analysis of genetic polymorphisms. Nature Reviews Genetics 3:380-390.

Ruokonen, M., L. Kvist, T. Aarvak, J. MarkKola, V. V. Morozov, I. J. Øien, E. E. Syroechкovsky, JR., P. Tolvanen, AND J. Lumme. 2004. Population genetic structure and conservation of the Lesser White-fronted Goose Anser erythropus. Conservation Genetics 5:501-512.

Schneider, S., J.-M. Keuffer, D. Roessli, and L. ExCOFFIER. 2000. ARLEQUIN, version 2.000: A software package for population genetics. University of Geneva, Switzerland.

Scribner, K. T., M. R. Petersen, R. L. Fields, S. L. Talbot, J. M. Pearce, and R. K. Chesser. 2001. Sex-biased gene flow in Spectacled Eiders (Anatidae): Inferences from molecular markers with contrasting modes of inheritance. Evolution 55:2105-2115.

Sefc, K. M., R. B. Payne, and M. D. Sorenson. 2005. Genetic continuity of brood-parasitic indigobird species. Molecular Ecology 14: 1407-1419.

Shimodaira, H., and M. Hasegawa. 1999. Multiple comparisons of log-likelihoods with applications to phylogenetic inference. Molecular Biology and Evolution 16: 1114-1116.

Sorenson, M. D., J. C. Ast, D. E. DimchefF, T. YuRI, AND D. P. Mindell. 1999. Primers for a PCR-based approach to mitochondrial genome sequencing in birds and other 
vertebrates. Molecular Phylogenetics and Evolution 12:105-114.

Sorenson, M. D., AND R. C. Fleischer. 1996. Multiple independent transpositions of mitochondrial DNA control region sequences to the nucleus. Proceedings of the National Academy of Sciences USA 93:15239-15243.

Swofford, D. L. 1999. PAUP*: Phylogenetic Analysis Using Parsimony (*and Other Methods), version 4.0. Sinauer Associates, Sunderland, Massachusetts.

Tiedemann, R., K. G. von Kistowski, and H. Noer. 1999. On sex-specific dispersal and mating tactics in the Common Eider Somateria mollissima as inferred from the genetic structure of breeding colonies. Behaviour 136:1145-1155.

Tubaro, P. L., AND D. A. Lijtmaer. 2002. Hybridization patterns and the evolution of reproductive isolation in ducks. Biological Journal of the Linnean Society 77:193-200.
U.S. Fish and Wildlife Service. 2005a. Waterfowl population status, 2005. U.S. Department of the Interior, Washington D.C.

U.S. Fish and Wilduife Service. 2005b. 2005 Pacific Flyway databook. U.S. Department of the Interior, Division of Migratory Bird Management, Portland, Oregon.

Webster, M. S., P. P. Marra, S. M. Haig, S. Bensch, AND R. T. Holmes. 2002. Links between worlds: Unraveling migratory connectivity. Trends in Ecology and Evolution 17:76-83.

Wilgenbusch, J., and K. de Queiroz. 2000. Phylogenetic relationships among the phrynosomatid sand lizards inferred from mitochondrial DNA sequences generated by heterogeneous evolutionary processes. Systematic Biology 49:592-612.

Associate Editor: K. P. Johnson

Appendix. Sampling details of North American Gadwall for each state or province.

\begin{tabular}{|c|c|c|c|c|c|}
\hline Population & Code & Flyway & $n$ & $r(12)^{\mathrm{a}}$ & Tissue source $^{\mathrm{b}}$ \\
\hline \multicolumn{6}{|c|}{ Known breeding populations } \\
\hline North Dakota & ND & Central & 36 & 5.28 & Blood (1), web (27), wing (8) \\
\hline Saskatchewan & SK & Central & 22 & 4.27 & Wing (6), nest (16) \\
\hline Alberta & $\mathrm{AB}$ & Central & 31 & 4.50 & Wing \\
\hline Utah & UT & Pacific & 22 & 6.00 & UWBM-70833, wing (3), nest (18) \\
\hline Washington & WA & Pacific & 19 & 2.99 & Web (14), nest (5) \\
\hline California: Central Valley & $\mathrm{Cacv}$ & Pacific & 32 & 3.75 & Nest \\
\hline California: Klamath Basin & CAkl & Pacific & 34 & 3.88 & Web \\
\hline \multicolumn{6}{|c|}{ Putative breeding populations ${ }^{c}$} \\
\hline Quebec & $\mathrm{QC}$ & Atlantic & $10(5)$ & 2.97 & Wing \\
\hline Manitoba & MB & Central & $7(6)$ & 3.77 & Wing \\
\hline Alaska: South-coastal & AKsc & Pacific & $4(17)$ & 3.40 & Wing \\
\hline \multicolumn{6}{|c|}{ Nonbreeding populations } \\
\hline Maritime Provinces & MP & Atlantic & 12 & 4.00 & Wing \\
\hline Delmarva & $\mathrm{DM}$ & Atlantic & 20 & 4.99 & Wing \\
\hline Arkansas & AR & Mississippi & i 14 & 5.29 & Wing \\
\hline Alaska: Kodiak Island & AKko & Pacific & 13 & 2.92 & Wing \\
\hline \multicolumn{6}{|c|}{ Widespread samples } \\
\hline \multicolumn{6}{|c|}{ Known and putative breeding ${ }^{c}$} \\
\hline Delaware & $\mathrm{DE}$ & Atlantic & 1 & & DMNH-83682 \\
\hline New York & NY & Atlantic & 1 & & Wing \\
\hline South Dakota & SD & Central & 6 & & Wing \\
\hline Alberta & $\mathrm{ABp}$ & Central & $0(3)$ & & Wing \\
\hline Wyoming & WY & Central & 1 & & Wing \\
\hline Montana: East & MTe & Central & 3 & & Wing \\
\hline Montana: West & MTw & Pacific & 1 & & Wing \\
\hline Colorado & $\mathrm{CO}$ & Pacific & $3(1)$ & & Wing \\
\hline
\end{tabular}


Appendix. Continued.

\begin{tabular}{lcllll}
\hline \hline Population & Code & Flyway & $n$ & $r(12)^{\mathrm{a}}$ & Tissue source $^{\mathrm{b}}$ \\
\hline Nevada & NV & Pacific & 1 & Wing \\
California: Mono Lake & CAml & Pacific & 5 & Feathers \\
Oregon & OR & Pacific & 1 & Wing \\
$\begin{array}{l}\text { British Columbia } \\
\text { Nonbreeding }\end{array}$ & BC & Pacific & 1 & Wing \\
North Carolina & NC & Atlantic & 1 & Wing \\
Maine & ME & Atlantic & 1 & Wing \\
Louisiana & LA & Central & 1 & Wing \\
Texas & TX & Central & 1 & Wing \\
California: Central Valley & CAnb & Pacific & 6 & Wing \\
Washington & WAnb & Pacific & 1 & GKD-173 \\
Adult males: Breeding & & & & \\
$\quad$ North Dakota & NDam & Central & 2 & Blood \\
California & CAam & Pacific & 3 & UWBM-68930, web (1), feathers (1) \\
\hline
\end{tabular}

${ }^{a}$ Allelic richness $[r(12)]$ is the number of alleles sampled per population standardized to a sample size $(n)$ of 12 (includes clade A and clade B haplotypes).

${ }^{b}$ Number in parentheses indicates the number of samples of that tissue source; "wing" refers to samples collected by the U.S. and Canadian wing surveys (see text) currently held at the University of Maryland Baltimore County; web = foot-webbing from trapped birds; nest = salvaged nesting material (i.e., egg membranes and feathers); vouchered museum specimens are indicated as follows: UWBM and GKD = University of Washington Burke Museum; DMNH = Delaware Museum of Natural History.

'For "putative breeding populations," the number of samples assignable to the local breeding population is given outside the parentheses, and the number that did not meet those criteria is given inside the parentheses. 